\title{
Dietary small bowel obstruction
}

\author{
Masashi Kusumoto, ${ }^{1}$ Masamichi Koganemaru, ${ }^{1}$ Goichi Nakayama, ${ }^{2}$ Ryoji Iwamoto ${ }^{1}$
}

1Department of Radiology, Kurume University School of Medicine, Kurume, Japan ${ }^{2}$ Department of Surgery, Kurume University School of Medicine, Kurume, Japan

\section{Correspondence to} Dr Masamichi Koganemaru, mkoganemaru@med.kurume-u. ac.jp
To cite: Kusumoto $M$, Koganemaru M, Nakayama $\mathrm{G}$, et al. BMJ Case Reports Published online: [please include Day Month Year] doi:10.1136/ bcr-2012-007950

\section{DESCRIPTION}

A 59-year-old man with no history of abdominal or intestinal surgery, trauma or psychiatric illness presented to our hospital with abdominal pain and vomiting. Physical examination revealed hyperactive bowel sounds and lower abdominal tenderness. Abdominal CT revealed a small bowel obstruction in the lower abdominal space, possibly due to obstruction of the fusiform low attenuation (-162 Hounsfield units) region (figure 1, arrows), and suspected ileal stricture on the anal side of the low-attenuation region. The region was similar to that of fat to air attenuation. Insertion of a nasogastric tube did not improve his condition, blood pressure decreased, and his symptoms were ingravescent. Emergency surgery was conducted to release the obstruction. Operative and pathological findings revealed mucosal damage and necrosis in the small intestine with no ileal stricture and adhesion; approximately $50 \mathrm{~cm}$ of the affected region was resected and an ingested $7.5 \mathrm{~cm}$ diameter shiitake mushroom was found (figure 2). The small bowel obstruction disappeared upon removal of the mushroom and the patient was discharged on postoperative day 17.

Given that mushrooms are rich in fibre, they absorb consumed oils, intestinal fluids and intestinal gases, and show very low attenuation on CT. Moreover, as in the present case, unintentionally swallowing one whole can cause bowel obstruction. Bowel obstruction most likely occurs in the small

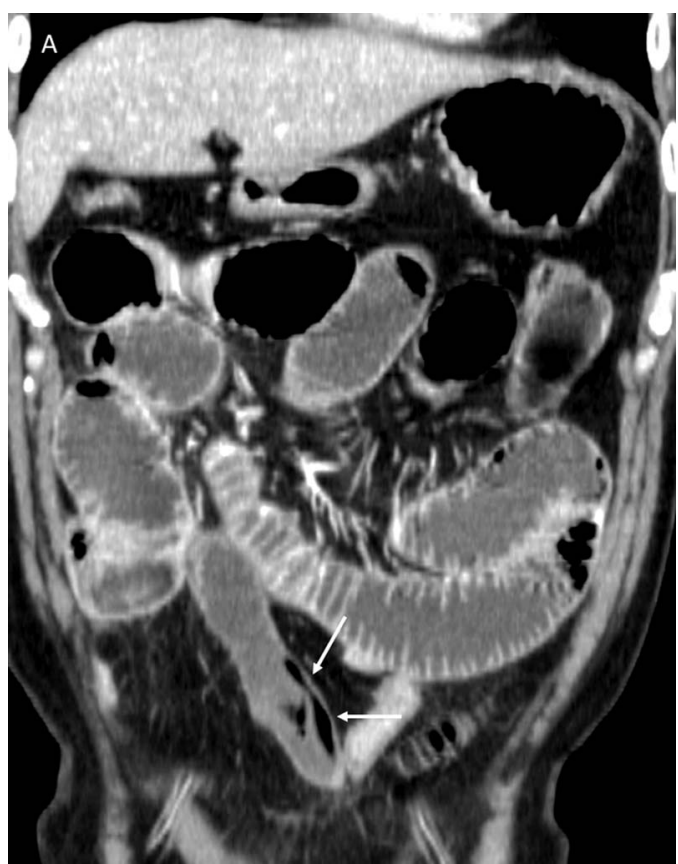

Figure $1 \mathrm{CT}$ revealed a small bowel obstruction and a very low attenuation area at the lower end of the dilated small intestine (arrows).

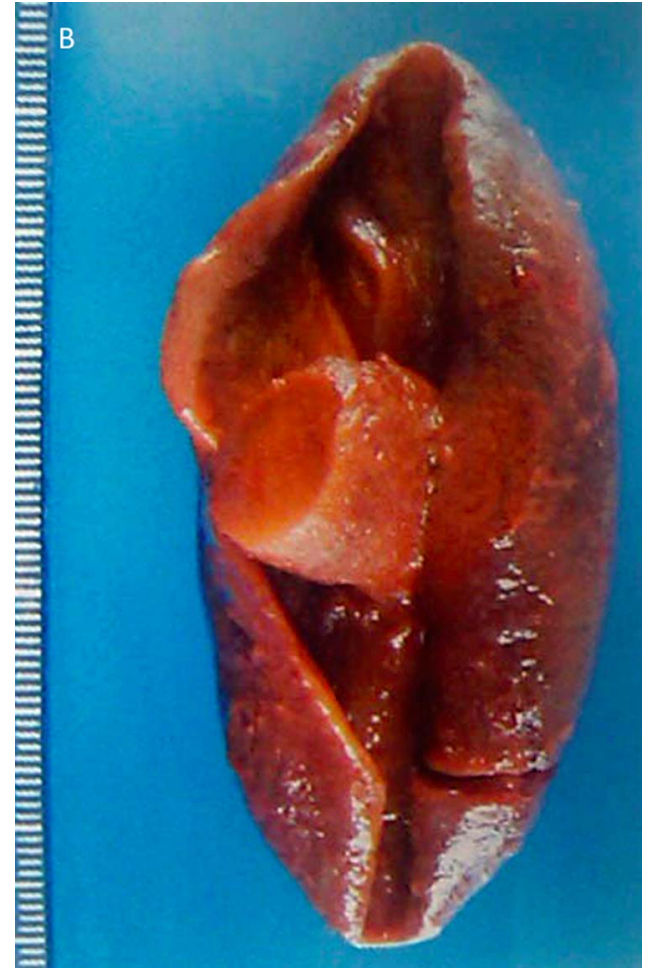

Figure 2 The small bowel obstruction was caused by a whole mushroom, which appeared as a very low attenuation area on CT.

intestine, given its diameter and weak movements. ${ }^{1} 2$ In addition, it sometimes occurs in the narrowest ileal segment in the oral side about $100 \mathrm{~cm}$ from the ileocaecal valve. ${ }^{3}$ The obstruction site is almost always normal. ${ }^{3}$

Our findings suggest that when a very low attenuation area is considered, the cause of dietary bowel obstruction by CT, a whole mushroom may be the culprit. While, such small bowel obstruction due to food substance is rare, it does occur occasionally, as in the present case.

\section{Learning points}

- Food substance is a potential factor in dietary small bowel obstruction.

- In the event of dilation of the lower end of the small intestine, a very low attenuation area on CT might be attributed to a whole mushroom.

\section{Competing interests None.}

Patient consent Obtained.

Provenance and peer review Not commissioned; externally peer reviewed. 


\section{REFERENCES}

1 Hitosugi M, Kitamura O, Takatsu A, et al. Autopsy case of duodenal obstruction from impacted mushroom. J Gastroenterol 1998;33:562-5.
2 Tan KB, Premasiri MK, Isaac J, et al. Mushroom bezoar: a rare cause of small intestinal obstruction. Pathology 2004;36:207-8.

3 Ward-McQuid N. Intestinal obstruction due to food. Br Med J 1950;13:1106-9.

Copyright 2013 BMJ Publishing Group. All rights reserved. For permission to reuse any of this content visit http://group.bmj.com/group/rights-licensing/permissions.

BMJ Case Report Fellows may re-use this article for personal use and teaching without any further permission.

Become a Fellow of BMJ Case Reports today and you can:

- Submit as many cases as you like

- Enjoy fast sympathetic peer review and rapid publication of accepted articles

- Access all the published articles

- Re-use any of the published material for personal use and teaching without further permission

For information on Institutional Fellowships contact consortiasales@bmjgroup.com

Visit casereports.bmj.com for more articles like this and to become a Fellow 